\title{
Simpósio de Editoração, Aniversário de Setenta anos e Scopus
}

\author{
Harley E. A. Bicas
}

Entre as riquíssimas sessões anuais de apresentação e discussão de temas de editoração, a cargo dos Arquivos Brasileiros de Oftalmologia e já tradicionais em nossos Congressos Brasileiros de Oftalmologia (anos ímpares), ou de Prevenção da Cegueira e Reabilitação Visual (anos pares), desde quando se realizou a primeira, em 1998, a deste ano merece receber menção especial, quer pela abrangência dos assuntos, quer pela homogeneidade das apresentações, todas em nível muito apropriado, quer por suas excelências pedagógicas. Em comemoração ao aniversário de setenta anos dos Arquivos, o conteúdo do Simpósio deve ser então, agora, ajustado para leitura, em meio eletrônico ou papel, para aproveitamento de eventuais interessados que não puderam presenciá-lo, agregando-se a temas de Metodologia Científica (assunto de outro magnífico painel de discussões, neste Congresso) e de regras sobre apresentação oral. Fazemos aniversário, mas quem ganha presente são os leitores...

De fato, neste ano os Arquivos Brasileiros de Oftalmologia comemoram seus setenta anos, desde quando começaram a circular. Como revista de Oftalmologia de periodicidade regular é a mais antiga da América Latina. Pois, a partir de sua primeira publicação, não conheceu períodos de interrupção, conservando, para nosso orgulho, uma regularidade inequivocamente invejável para um órgão desse tipo. Aliás, seja no Brasil, como no exterior, não foram poucas as tentativas de publicar revistas de Oftalmologia que, entretanto, apenas tiveram durações efêmeras, frustrando ideais, face às dificuldades de editoração, tanto de ordem financeira, quanto da disponibilidade de conteúdo (quantidade e qualidade) das matérias. Realmente, até algumas revistas de elevadíssimo padrão internacional não podem se jactar dessa continuidade.

Contudo, isso não é fácil, mesmo hoje, com prestígio já consolidado e como revista científica oficial do Conselho Brasileiro de Oftalmologia. Imagine-se, então, como teriam sido os percalços dos primeiros tempos. Convém relembrá-los.

Tudo começou por obra e graça da família Belfort Mattos. Com Waldemar, propugnador, fundador e mantenedor da revista até quando nos deixou (1956), seguido por seu filho, Rubens (até 1991) e por seu neto, Rubens Júnior, foi necessária muita fé no ideal, muita persistência no empreendimento, muito trabalho e empenho, muito dinheiro. Por 39 anos, a família apoiou o crescimento e a maturidade da revista, a ela se desvelando com preocupações, com carinho e com sacrifícios de toda ordem, tempo e patrimônio. Que o diga D. Rosinha Belfort Mattos, sobre como foi dividir atenções do sogro, do marido e do filho com esse ideal, decidindo, por fim, também imergir as suas no mesmo sentido. Uma aposta de alto risco, a que a Oftalmologia brasileira decidiu que não podia ficar indiferente: em 1977, o Conselho Brasileiro de Oftalmologia passou a patrociná-la. Mas enganou-se quem pensasse que, então aliviada dos encargos financeiros, a família se omitisse. Por mais 22 anos continuou em sua linha de esforços e dedicação para que a revista se tornasse cada vez maior e melhor, liderando suas conquistas até setembro de 1999. E muito se engana, ainda, quem ache que a história terminou: como a uma filha, ou neta, embora já em suas plenitudes de vida, a preocupação de pais, ou avós, segue como se menininha a filha, ou neta, ainda fosse. Desde então, os Arquivos Brasileiros de Oftalmologia foram definitivamente recebidos pelo Conselho Brasileiro de Oftalmologia, inclusive (e como se diz) de papel passado, por doação de direitos, por escritura pública, no ano seguinte. O reconhecimento da Oftalmologia brasileira se fez, em parte, pela inclusão de um membro, ou sucessor, da família Belfort Mattos no Conselho Administrativo da revista, seu colegiado maior.

Nestes anos mais recentes, a revista tem colhido os frutos de sua maturidade e os benefícios da excelente qualidade da oftalmologia brasileira. Aumentou o volume de suas publicações e recebeu novos reconhecimentos de mérito (SciELO, MEDLINE e EMBASE), somando-se aos que já possuía. É, hoje, a única revista de Oftalmologia da América Latina a se orgulhar do prestígio de sua indexação pelas mais respeitadas agências internacionais que disso cuidam. Há pouco, os impactos de nossos trabalhos publicados e autores passou a ser medido pela Scopus, uma das duas mais importantes e influentes agências de divulgação eletrônica das bases de dados científicos mundiais, a mais recente prova de nossos méritos. E esperamos que, em breve, estejamos igualmente reconhecidos pelo ISI Web of Knowledge, pedra da coroa, incensada pelas agências de fomento à pesquisa e Universidades brasileiras como determinante de valores de um trabalho científico, ou do veículo que o propaga.

Obviamente, a periodicidade de suas publicações, a quantidade e a qualidade de seus artigos, o reconhecimento de valor pelas indexações e divulgações mais amplas de seus conteúdos, a medição de impactos, tudo isso fator distintivo para uma revista científica - a fazê-la respeitada por Universidades e agências de fomento à pesquisa - não esgotam a necessidade de aperfeiçoamentos. Ao contrário, nesse patamar elevado, apartada de suas congêneres latino-americanas e 
digna representante delas, categorizada entre o que melhor existe na oftalmologia mundial, as exigências se tornam ainda maiores. Para isso, contamos com o decidido apoio dos autores que nos prestigiam pelo encaminhamento de seus trabalhos; de analistas e do corpo editorial da revista, que contribuem para que as condições de nossas publicações sejam, sempre e cada vez mais, as melhores possíveis. Chegando à primeira divisão das revistas internacionais, a busca seguinte é a de estar entre as melhores dessa elite.

Não há fim na busca das finalidades. Este é o destino desta jovenzinha de setenta anos: alcançado um objetivo, vislumbrar outro mais à frente.
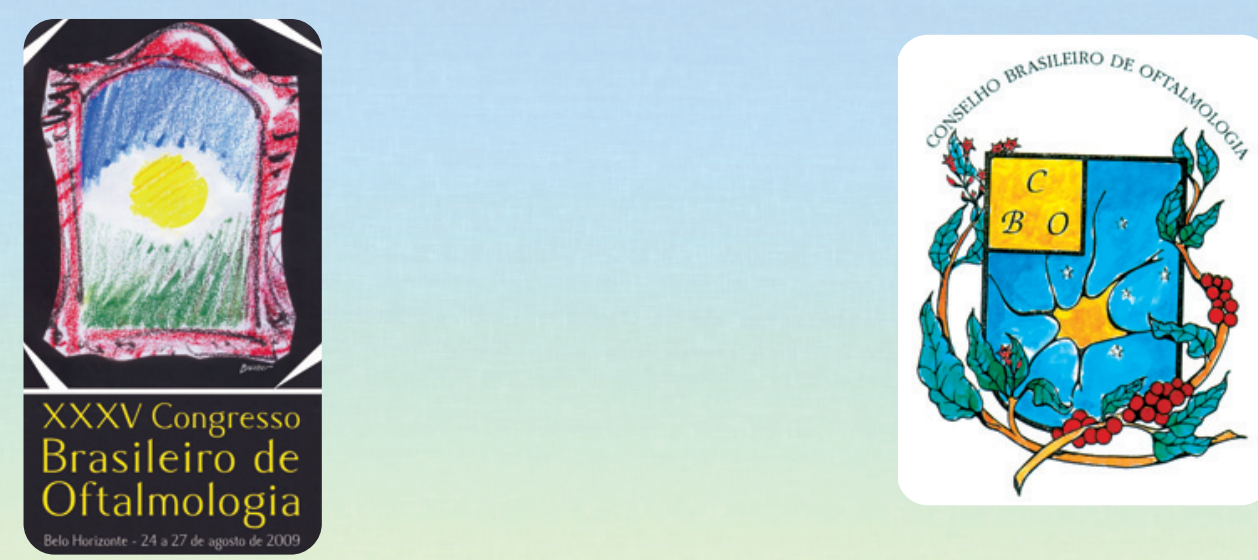

XXXV CONGRESSO

\title{
BRASILEIRO DE OFTALMOLOGIA
}

\author{
24 a 27 de Agosto de 2009 \\ Expominas - Centro de Convenções - Belo Horizonte
}

